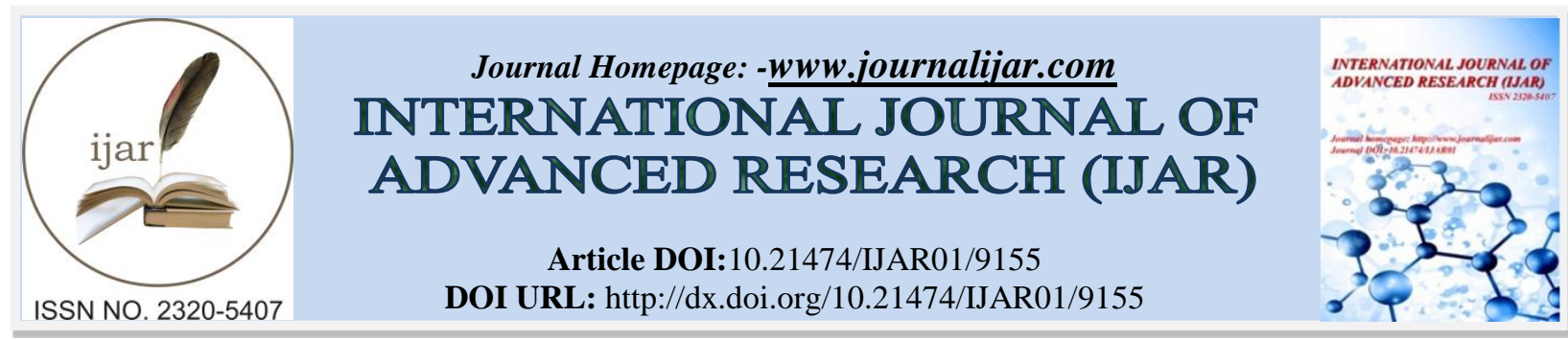

RESEARCH ARTICLE

\title{
CHANGES IN HEMATOLOGICAL PARAMETERS OF SCHIZOTHORAX RICHARDSONII (GRAY 1832)INFECTED WITH SAPROLEGNIASIS IN FARMED CONDITION.
}

Uzma Siddiqui $^{1}$, H.C.S.Bisht ${ }^{1}$ and N. N. Pandey ${ }^{2}$.

1. Zoology Department, DSB Campus, Kumaon University, Nainital 263002, Uttarakhand.

2. Directorate of Coldwater Fisheries Research, Bhimtal-263136, Nainital, Uttarakhand.

\section{Manuscript Info}

Manuscript History

Received: 24 March 2019

Final Accepted: 26 April 2019

Published: May 2019

Key words:-

Hematological parameters, Schizothorax

richardsonii, Saprolegnia Leucocytes.

\section{Abstract}

Snow trout (Schizothorax richardsonii) is an important indigenous coldwater fish having potential for its cultivation in Indian Himalayan region. Hematology provides an index of physiological status of fish and its study is important for health status and wellness of the growing fish. Hematology is a tool for diagnosis of diseased fish. An attempt has been made to explore the hematological parameters of snow trout infected with Saprolegnia spp and comparison of these parameters with healthy fish. Blood parameters like Hemoglobin ( $\mathrm{Hb})$, Total Erythrocyte Count (TEC), Total Leucocyte Count (TLC) and haematocrit (Hct) were observed for the healthy as well as infected fish. TEC and Hct increased significantly but there was significant decrease in TLC in the infected fish in the later stages of infection. The data was analysed by one-way ANOVA which reflected significant values of hematological parameters of Schizothorax richardsonii that are significantly different from the healthy fish due to the infection of saprolegnia spp. In the present investigation, alterations in important hematological parameters due to fungal infection may be used as diagnostic tool for the fungal infected snow trout. Further, this information would be helpful for the remedy and therapeutic use of drugs against fungal infection. Study may be referred for the further investigation in this line.

Copy Right, IJAR, 2019,. All rights reserved.

\section{Introduction:-}

Fish are important source of food for nutritional and livelihood security to the people dwelling in hills. Snow trout (Schizothorax richardsonii) is a major fish in coldwater resources in many countries. In farmed fish, some changes such as stress and immunosuppression allow infection to develop quickly (Pickering, 1994). Saprolegniasis fungi is the most common pathogenic fungi. Saprolegnia infection in fish has been reported earlier (Roberts, et.al., 2003, Chauhan and Chauhan, et.al.,2014.). Some other workers ( Bruno and Poe,1996, Hatai and Hoshiai, 1994.) also reported Saprolegnia infection in fish. The fish infected with Saprolegnia are easily recognized by the cotton-like white to greyish patches on the skin and gills visible to the naked eye (Stueland, et. al., 2005). The infection progresses very quickly and often results in mortality and can cause huge losses of both fish and ova (Stueland,

Corresponding Author:-Uzma Siddiqui.

Address:-Zoology Department, DSB Campus, Kumaon University, Nainital 263002 , Uttarakhand. 
et.al., 2005; Howe and Stehly, 1998). The study of infected fish is essential to make efforts to determine the efficacy of various antifungal treatments (Howe and Stehly, 1998), and to understand the mode of action of fungal infection and the resistance capability of fish.

Saprolegenia invades epidermal tissue, generally beginning on the head or fins and can spread over the entire surface of body (Willoughby, 1978) reported that mature fishes of both sexes and eggs are prone to fungal infection persisting from November to the end of March when the water temperature ranges between $8.5^{\circ} \mathrm{C}$ to $11.5^{\circ} \mathrm{C}$ and the infection vanishes automatically as the temperature rises to above $11.5^{\circ} \mathrm{C}$. These findings were reported in the present study and thus are in coherence with reported values. Saprolegniasis contributes to heavy mortality among fishes and are widely spread in fresh water ecosystems, affecting wild and cultured fishes and are considered as the single contributing cause of economic loss in aquaculture second only to bacterial diseases in economic importance (Hussain, et.al., 2001). In the final stage of the disease, protein deficiency leads to atrophy of skeletal muscles and suppression of collagen synthesis. Lack of collagen is reported to lead to poor regeneration of lesions on the skin (Willoughby and Pickering, 1977; Khulbe, et.al., 1995).

The physiological state of fish health is determine by Hematological parameter provides. Mycotic infection affected the blood parameters of fish have been reported (Banerjee and Bhagat, 1986, Qureshi, et.al., 2001 and Shah, 2010). Since fungi are pathogenic to fish, it causes various levels destruction in the tissue. Hematological values changes depending on the fish species, age, cycle of sexual maturity and condition of health (Hrubec, et.al, 2000). Hematological tests have shown useful information in detection and diagnosis of metabolic disturbances and diseases in fishes. The present study was designed to investigate the changes in hematological parameters of Saprolegnia infected fish to find out the extent of infection, which may be a diagnostic tool for the Saprolegniasis in a wide spread indigenous coldwater fish, snow trout.

\section{Material and Methods:-}

\section{Study site, sample collection, blood sample collection}

Schizothorax richardsonii is a fresh water teleost which belongs to family Cyprinidae. For this study samples of farm raised fish were collected from fish farm of ICAR-Directorate of Coldwater Fisheries Research, Bhimtal, Uttarakahnd $\left(29.3461^{\circ} \mathrm{N}, 79.5519^{\circ} \mathrm{E}\right)$. For this study 15 fishes from healthy stock and 15 fishes from infected stock measuring average values of $20 \pm 5 \mathrm{~cm}$ in length and $40 \pm 3 \mathrm{gm}$ in weight were used. The blood samples were collected using a sterile plastic disposable syringe of needle size 24 gauge already moistured with EDTA ( $2 \mathrm{ml}$ ) by venipuncture of caudal vein, that lies just ventral to the spinal cord, the blood is collected either by lateral or ventral approach of caudal vein. The blood was immediately transferred to the anticoagulant vial (EDTA Vials).After the collection of blood following hematological parameters were analyzed for the present study, hemoglobin(Hb),total erythrocyte count(RBC), total leukocyte count(WBC), haematocrict(Hct), mean corpuscular hemoglobin(MCH), mean corpuscular hemoglobin concentration(MCHC), and mean corpuscular volume(MCV) respectively. Simultaneously the water parameters were also analysed during the study period under the captive condition. Peripheral blood film (PBF) test were performed on thin blood smears fixed in methanol and stained with Leishman's stain.

\section{Result and Discussion:-}

A total number of fifteen healthy and fifteen saprolegniasis infected Schizothorax richardsonii were studied for hematological parameters under the farm conditions. Hematocrit, erythrocytes count and haemoglobin concentrations are the most readily determined hematological parameters under the field and hatchery conditions (Bhasar and Rao, 1990). The infected fish showed white fungoid patches, ulceration in body and lost epidermis in the later stages of infection.(fig.1). The results reveal that all hematological parameters showed overall noticeable changes in infected fish in the later stages.

The mean value of MCV in infected and healthy fish were 245.66 and 433.53 respectively with significant difference $(\mathrm{P}<0.05)$. The value of MCV was observed highest in the healthy fish then the infected fish in the later stages of infection as MCV has a inverse relation with TEC.A significant $(\mathrm{P}<0.05)$ increase was observed in $\mathrm{Hb}(\mathrm{g} / \mathrm{dl}), \operatorname{RBC}\left(10^{6} / \mathrm{mm}^{3}\right), \mathrm{Hct}(\%)$, when compared with the healthy fish, which is due to increase demand of oxygen. A significant decrease $(\mathrm{P}<0.05)$ were observed in the values of White Blood Corpuscles in the later stages of infection. The decrease in WBCs is due to hemodilution. Highest rate of mortality was observed in the infected fish. There was decreasing trends in the values of MCHC in the infected fish with no significant difference. 
Leucocytes are the second major cells after erythrocytes in the blood of fishes that are repeatedly used as indicators of health status because these are essential constituents of innate immune defense and involved in regulation of immunological functions in the aquatic organisms (Ballarin et al. 2004). In the present study, we have observed significant difference in leukocyte count $(\mathrm{p}<0.05)$ at later phase of infection than at the early and healthy ones. The decrease in leucocytes is due to increased secretion of corticosteroids and hemodilution (McLeay,1973 and Tort et.al.,1987). The MCV gives an indication of the status or size of the erythrocytes and reflects an abnormal or normal cell division during erythropoiesis showing inverse relation with TEC, this inverse relation justifies the decline in MCV at later stages of infection in the present study. The macrocytosis is probably an adaptive response through the influx of immature erythrocytes from the hematopoietic tissues to the peripheral blood to make up the reduced erythrocytes number and decreased hemoglobin concentration (Rehulka et al., 2005). MCHC shows decreasing trend in infected fish with no significant difference, which is due to microcytic anemia, loss of stamina to cope with infection and immature erythrocyte resulted in low count of MCHC. Low MCH with significant difference $(\mathrm{P}<0.05)$ was observed in the present study causing the skin bruise easily.

Table 1:-

\begin{tabular}{|l|l|l|}
\hline Hematological parameters & Healthy Mean \pm SE & Infected Mean \pm SE \\
\hline Hb $(\mathbf{g} / \mathbf{d l})$ & $9.01 \pm 0.43^{*}$ & $11.65 \pm 0.24^{*}$ \\
\hline Hct $(\%)$ & $26.93 \pm 1.18^{*}$ & $34.6 \pm 1.03^{*}$ \\
\hline $\mathbf{W B C}(\times \mathbf{1 0} / \boldsymbol{\mu l})$ & $15.96 \pm 0.79^{*}$ & $11.94 \pm 1.28^{*}$ \\
\hline $\mathbf{R B C}(\times \mathbf{1 0} / \boldsymbol{\mu l})$ & $0.70 \pm 0.09^{*}$ & $1.52 \pm 0.11^{*}$ \\
\hline $\mathbf{M C V}(\mathbf{f l})$ & $433.53 \pm 52.35^{*}$ & $245.66 \pm 18.73^{*}$ \\
\hline MCH$(\mathbf{p g})$ & $153.50 \pm 16.15^{*}$ & $83.15 \pm 6.66^{*}$ \\
\hline MCHC(\%) & $37.44 \pm 2.84$ & $33.86 \pm 0.59$ \\
\hline
\end{tabular}

*shows significant difference $(\mathrm{p}<0.05)$ between healthy and infected fish with the mean \pm SE in the hematological parameters.

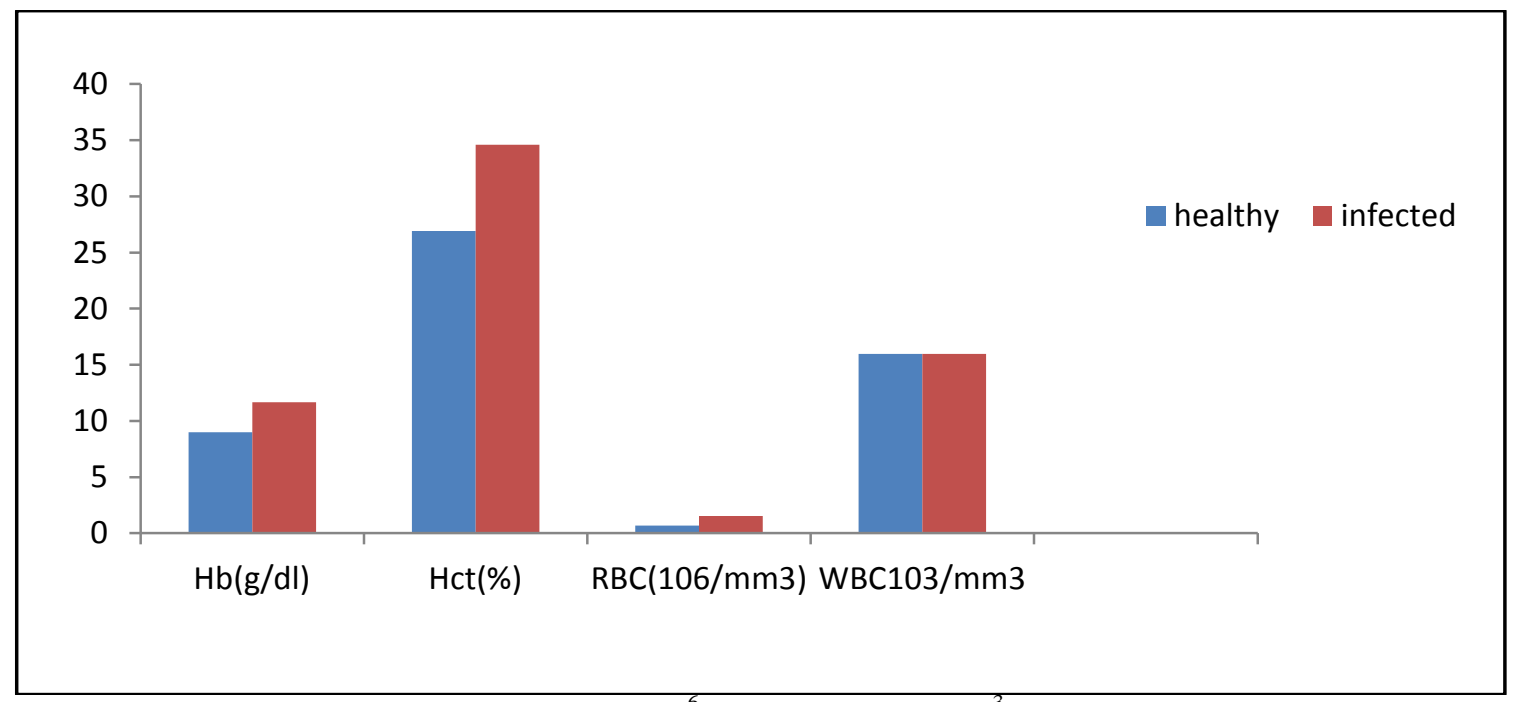

Fig 1:-Comparison of $\mathrm{Hb}(\mathrm{g} / \mathrm{dl})$, Hct $(\%), \mathrm{RBC}\left(10^{6} / \mathrm{mm} 3\right)$ and $\mathrm{WBC}\left(10^{3} / \mathrm{mm} 3\right)$ between healthy and infected $\mathrm{S}$. richardsonii. 


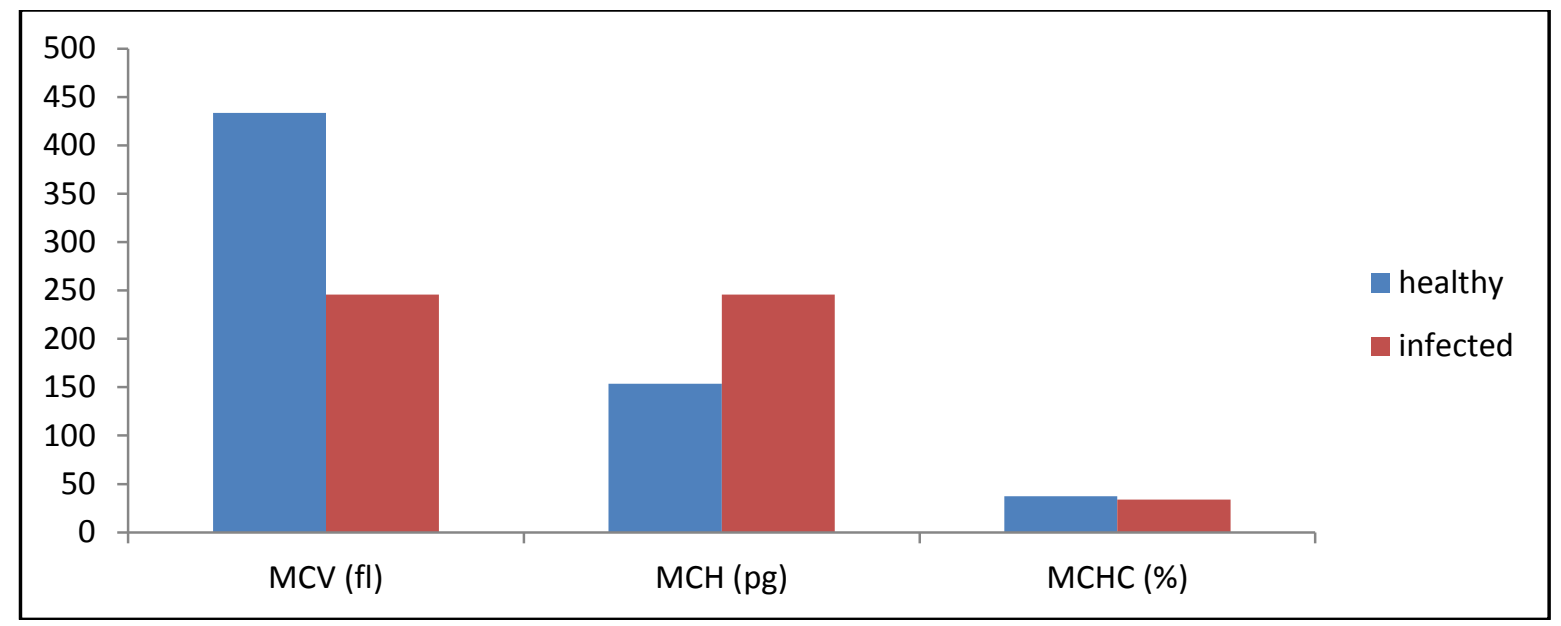

Fig 2:-Comparison of MCV (fl), MCH (pg) and MCHC (\%) between healthy and infected S. richardsonii

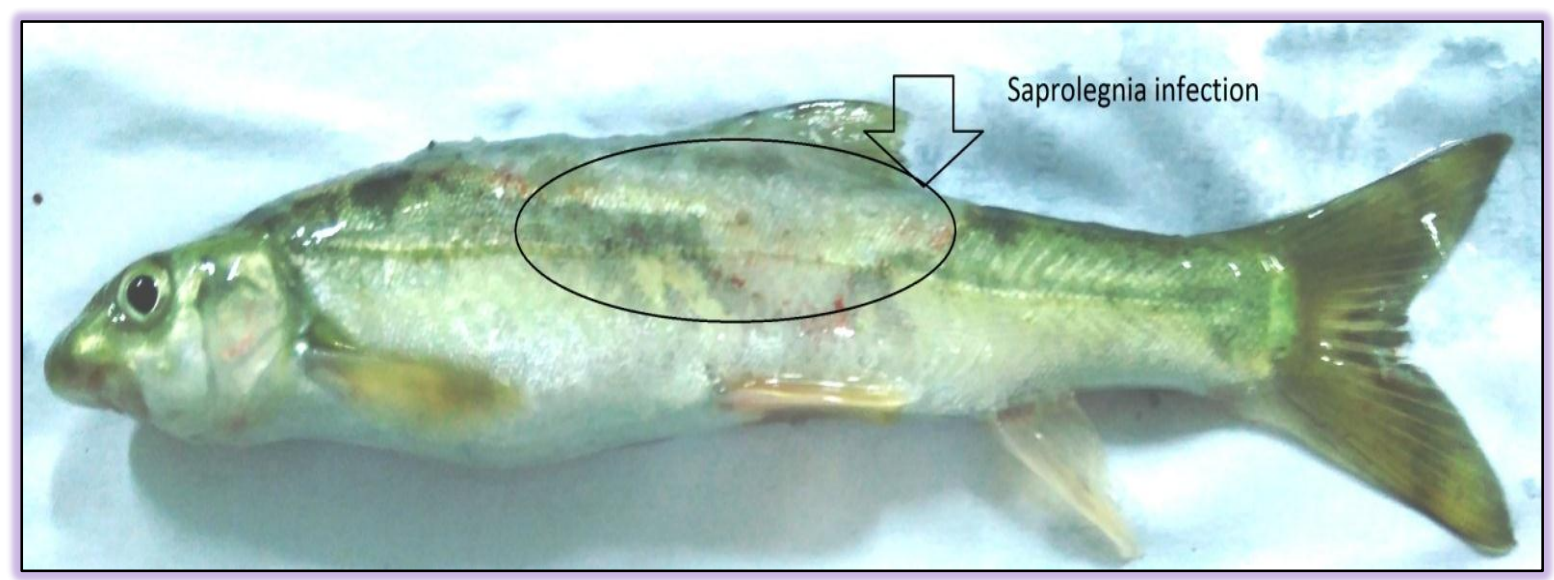

Fig 3:-S. richardsonii infected with Saprolegnia sp.

\section{Conclusion:-}

It can be concluded that changes in important hematological parameters due to fungal infection is an indicator of saprolegniasis infection in Schizothorax richardsonii. The present study, investigation is of importance as it provides the database for reference intervals for the healthy as well as later stage infected fish hematological values and may be use as a tool to monitor the health status of this fish.

\section{Acknowledgements:-}

The authors are thankful to Director, Directorate of Coldwater Fisheries Research (DCFR), Bhimtal for providing the opportunity to carry out this work along with their valuable guidance, useful suggestions and facilities during the research.

\section{Reference:-}

1. Ballarin, L., Dall'Oro, M., Bertotto, D., Libertini, A., Francescon, A., Barbaro, A .2004. Haematological parameters in Umbrina cirrosa (Teleostei, Sciaenidae): a comparison between diploid and triploid specimens. Comparative Biochemistry and Physiology Part A: Molecular and Integrative Physiology 138, 45-51.

2. Banerjee, V., and Bhagat, R.P. 1986. Hematology of Indian fresh water eel Amphipo noucuchia (Ham.), Erythrocyte count and related parameters with special reference to body length, sex and season. Comp Physiol Ecol, 11(2): 21-27.

3. Bhasar, B.R., and Rao, K.S. 1990. Use of haematological parameters as diagnostic tools in determining the health of milk fish, Chanos chanos (Forskal), in brackish water culture. Aquaculture and Fisheries Management 21: $125-129$. 
4. Bruno, D.W., and Poe, T.T. 1996. A Colour Atlas of Salmonid Diseases. Academic Press, London 189.

5. Chauhan, R., Beigh, A.H. and Bhatt, M.H. 2014. Histopathological manifestations in commercially important fish, Clarias batrachus (1.) found infected with Saprolegnia diclina. Indo Am J of Pharm Res. (4)2: 1168-1172.

6. Hatai, K., and Hoshiai, G.I. 1994. Pathogenicity of Saprolegnia parasitica Coker. In, Mueller, G.J, Ed. Salmon and Saprolegniosis. U.S. Department of Energy, Bonneville Power Administration, Portland 87-98.

7. Howe, G.E. and Stehly, G.R. 1998. Experimental infection of rainbow trout with Saprolegnia parasitica. J. Aquat. Anim. Health. 10:397-404.

8. Hrubec, T.C., Cardinale, J.L. and Smith, S.A., 2000. Haemotology and plasma chemistry reference intervals for cultured tilapia (Oreochromis hybrid). Veterinary Clinical Pathology, 29(1),7-12.

9. Hussain, M.M., Hatai, A.K. and Nomura. 2001. Saprolegniasis in Salmonids and their eggs in Japan. Journal of Wildlife Diseases, 37, 204-207.

10. Khulbe, R.D., Joshi, C. and Bisht, G.S., 1995. Fungal diseases of fish in Nanak Sagar, Nainital, India. Mycopathologia, 130(2), 71-4.

11. Malte, H. 1986. Effects of aluminum in hard, acid water on metabolic rate, blood gas tensions and ionic status in the rainbow trout. J. Fish Bio 129: 187-198.

12. McLeay, D.J. 1973. Effects of a 12-hr and 25-day exposure to Kraft pulp mill effluent on the blood and tissues of juvenile coho salmon, Oncorhynchus kisutch. J. Fish. Res. Board Canada. 30: 395-400.

13. Pickering, A.D., Willoughby, L.G.1982. Saprolegnia infections of Salmonid fish. In Roberts, r.J.ed., Microbial diseases of fish. Academic Press, London. pp.189

14. Qureshi TA, Chauhan R and Mastan SA. 2001. Hematological investigations on fishes infested with fungal growth. J of Envr. Biol. 22(4) 273-276.

15. Rehulka, J. and Minařík, B. 2005. Blood parameters in brook trout Salvelinus fontinalis (Mitchill, 1815), affected by columnaris disease. Journal of Aquaculture Research, 38 (11):1182-1197.

16. Robert, M.D., Wise, D.J., and Jeffery, S.T.2003. Saprolegniasis (winter fungus) and Branchiomycosis of commercially cultured channel cat fish. SRAC.

17. Shah, S.L. 2010.Impairment in the hematological parameters of tench (Tinca tinca) infected by Saprolegnias. Turk J Vet Anim Sci, 34(4), 313-318.

18. Stueland, S., Hatai, K., and Skaar, I. 2005. Morphological and physiological characteristics of Saprolegnia spp. Strains pathogenic to Atlantic salmon, Salmo salar L. J. Fish Dis., 28:445-453.

19. Tort, L., Torres, P., Flos, R. 1987. Effects on dogfish haematology and liver composition after acute copper exposure. Comp. Biochem. Physiol. C. 87: 349-353.

20. Willoughby, L.G. and Pickring, A., 1977. Viable Saprolegniales spores on the epidermis of Salmonid fish (Salmo trutta and Salvilenus alpious). Transactions of the British Mycology Society, 68(1), 91-95.

21. Willoughby, L.G.1978. Saprolegniasis of Salmonid fish in windermine: A critical analysis, Journal of Fish Diseases.1:151-167. 